\title{
Review of the latest research on coal, environment, and clean technologies
}

The Mining-Geology-Petroleum Engineering Bulletin UDC: 550.8

DOI: $10.17794 / \operatorname{rgn} .2018 .3 .2$

Review scientific paper

\author{
Gordana Medunić'; Deepti Mondol ${ }^{2}$; Ankica Rađenovićc; Sadhana Nazir ${ }^{4}$ \\ ${ }^{I}$ University of Zagreb, Faculty of Science, Department of Geology, Zagreb, Croatia \\ ${ }^{2}$ Ewing Christian College, Zoology Department, Allahabad, India \\ ${ }^{3}$ University of Zagreb, Faculty of Metallurgy, Sisak, Croatia \\ ${ }^{4}$ Pandu College, Zoology Department, Guwahati, India
}

\begin{abstract}
Fossil fuels, coal in particular, are indispensable sources of energy necessary for today's technological and economical progress throughout the world. Their burning releases numerous environmental contaminants, like $\mathrm{CO}_{2}, \mathrm{SO}_{2}$, and a range of organic and inorganic compounds. Arguably, however, and despite the fact that these emissions have resulted in air pollution and regional acid rain problems, there is no evidence yet of their usage completely replaced by a low- $\mathrm{CO}_{2}-$ producing energy source. Coal, due to its unique composition and characteristics, has been actively investigated by scientists and technologists from various disciplines in a search for economically valuable metals and medically active substances. Also, coal is used universally for the fabrication of new nanomaterials in laboratories, and utilized in wastetreatment and clean-coal technologies. The aim of this paper is to focus on the latest advancements in coal research of leading international scientists from India, China, and the USA. Also, this paper is briefly presenting selected papers of several Indian and Croatian research groups addressing environmental issues and emerging waste-treatment technologies. Although the two countries are different from a geographical, historical, economical, and industrial point of view, they both have been linked with coal extraction and its usage in power generation and associated heavy industries.
\end{abstract}

Keywords:

coal, waste, environmental pollution, clean-coal technology, bioremediation.

\section{Introduction}

Coal is the most abundant specimen among the fossil fuels, i.e. the coals, oil shales, oil, and gas deposits of Earth. It is the deposit of organic matter - the remains of dead plants and animals - entrapped in sedimentary rocks at the site of organic matter growth many millennia ago. Coals generally contain $10-30 \%$ of inorganic material made up of clay minerals, quartz silt, and sand, thus contributing to metal emission load upon their combustion (Saikia et al., 2009; Singh et al., 2015a; Dai et al., 2016). By igniting coal, the Sun energy stored in it is being released, thus producing heat and energy needed for industry, and generally, sustaining nations' standards of living. However, the fuel burning emissions are the largest source of anthropogenic greenhouse gases and aerosols (Kumar et al., 2017a). Also, some European and Asian countries have experienced devastating damage to the environment and to the human health owing to many years of intensive coal mining/burning and associated metallurgy in the past (Helios Rybicka, 1996; Sofilić et al., 2013; Oliveira et al., 2014; Banerjee et

Corresponding author: Gordana Medunić gmedunic@geol.pmf.hr al., 2016; Naik, 2016). Notwithstanding, in the current situation of high-energy demand, coal still remains a vibrant industry. According to the World Coal Association (WCA), proven reserves of coal are much greater than those of oil and gas combined, and are sufficient to supply more than 100 years of production at 2015 levels. However, Höök et al. (2010) emphasize that a peak in global coal production should be reached in 2020-2030, and that 'This is much sooner than commonly thought, and if this is correct it would represent a significant challenge for future energy supplies'. Furthermore, the latest WCA reports note that coal still makes up 29\% of global primary energy and $41 \%$ of global electricity.

Coal, being the most important energy source in parts of the world lacking pollution-control technology, adversely affects the global atmosphere (Banerjee et al., 2016). It is the most complex geological material, composed of organic compounds (Saikia et al., 2007), $\mathrm{H}_{2} \mathrm{O}$, oil, $\mathrm{CH}_{4}$, and all the chemical elements, together with a wide variety of minerals (Finkelman, 1994; Rađenović, 2006). According to the 1990 US Clean Air Act Amendments, the hazardous trace elements $\mathrm{As}, \mathrm{Be}, \mathrm{Cd}, \mathrm{Co}, \mathrm{Cr}$, $\mathrm{Hg}, \mathrm{Mn}, \mathrm{Ni}, \mathrm{Pb}, \mathrm{Sb}$, and $\mathrm{Se}$ are listed as key toxic air pollutants (U.S. EPA, 1990). The original US Clean 
Air Act, implemented by the Environmental Protection Agency in 1971, and the amendments to the act in 1977 and 1990, have required a substantial evolution of the quality of coal in terms of the reduction of $\mathrm{SO}_{2}$ and $\mathrm{NO}_{x}$ emissions (Hower et al., 1999). Low-quality coals have high ash, high sulphur, and high trace element contents. Due to stringent environmental regulations, various physical, chemical, and microbiological methods have been developed to solve the hazardous impact of these substances on the environment (Rađenović, 2004; Mishra et al., 2007; Singh et al., 2013, 2014; Baruah et al., 2016; Saikia et al., 2016; Kumar et al., 2017b). Also, the combustion behaviour of various types of coal is dependent on their ash properties (Mishra et al., 2016).

Previously, Rađenović et al. (2016a) outlined comparative information on geography, meteorology, industry and environmental policy in Croatia and India. Briefly, Croatia is a southeastern European country, having a total area of $56,542 \mathrm{~km}^{2}$, and sharing boundaries with six countries the length of which amount to $2,375 \mathrm{~km}$. On the other hand, the total area of the Republic of India is $3,287,590 \mathrm{~km}^{2}$, which is nearly 60 times larger than Croatian territory. The total length of the boundary with neighboring countries is $21,103 \mathrm{~km}$, i.e. nearly 9 times the length of the Croatian boundaries, of which 7,000 $\mathrm{km}$ is coastline. In relation to coal, the most important as well as the largest coal-mining (superhigh-organic-sulphur Raša coal, SHOS) area in Croatia (Medunić et al., 2016a) is situated at the eastern part of the Istrian peninsula (see Fig. 1 in Rađenović et al., 2016a). It was exploited from the 18th century until the late 1990s. There is also a location of the sole Croatian coal-fired Plomin power plant (PPP), which started with operation in 1970 using SHOS Raša coal enriched in S, up to $13-14 \%$ (Medunić et al., in press), while imported low-S coal has been used for the last 17 years. India, having almost $7 \%$ of the world's total coal reserves, belongs to the socalled Big Six group, i.e. the USA, Russian Federation, China, India, Australia, and South Africa. These countries account for nearly $80 \%$ of the world's coal production, with $43 \%$ from China alone. Coal has been mined in India for more than 230 years (Höök et al., 2010). The Integrated Energy Policy Committee, set up by the Government of India in 2004, has emphasized the continuing dominance of coal in the Indian Energy Sector over the next 25 years. According to the Geological Survey of India, the coal reserves in India are estimated to be some 308.802 billion tons, extending up to depths of 1,200 meters. Only $12.5 \%$ of them belong to the coking type, while the remaining $87.5 \%$ is thermal coal. They are mainly distributed in the states of Bihar and Telangana. Chikkatur et al. (2009) note that coal currently accounts for more than $50 \%$ of total primary commercial energy supply in the country and for about $70 \%$ of total electricity generation. According to these authors, the ash content in Indian coals have been increasing over the past three decades, primarily because of increased opencast mining and production of coal from inherently inferior grades of resources. As a consequence of the high ash content in Indian coals, at least $4,047 \mathrm{~m}^{2}$ of land is needed to store ash per one MW of installed capacity, and there are many large power plants with more than $4,047,000 \mathrm{~m}^{2}$ of land dedicated only for ash storage (Chikkatur et al., 2009). The authors conclude that good coal-power policies encompass the following measures: improving the efficiency of all elements of the country's existing power system, deploying high efficiency technologies in the short term, and devising a long-term strategy for developing and deploying advanced coal power technologies.

The objectives of this paper are to present the latest advancements in coal research, carried out by leading international scientists from India, China, and the USA, and to outline selected Indian and Croatian studies addressing environmental contamination and waste-treatment technologies.

\section{The latest multidisciplinary environmental and clean-coal technology research in India, China, and the USA}

Detrimental impacts of coal mining, coal combustion, and coal by-product disposal on the environment are well documented in scientific literature. They are mainly related to acid-mine (S) drainage problems (Burgos et al., 2012), selenium (Se) leaching from ash, and its concomitant mobility (Dreher and Finkelman, 1992; Harkness et al., 2016), and soil, air, and water pollution (Baruah et al., 2006; Oliveira et al., 2014; Saikia et al., 2015a; Nišić et al., 2016). That was inevitable due to lack of a proper legislative and non-existent clean-coal technologies in the past. Today, the situation is getting substantially improved from both points of view. Society members are aware of the fact that energy is necessary, and coal resources are in a high demand for that purpose. Therefore, clean-coal technologies are being actively developed throughout the world coal laboratories and implemented in industrial devices. Coal is also necessary for various technological and medical utilizations and applications, and this statement will be elaborated by the following text.

Briefly, clean-coal technologies are focused on the removal of mineral matter (ash yield) and sulphur from coal. Sulphur emissions generate hazardous sulphate aerosols and corrode the boiler tubes during operation. The mineral matter in coal forms ash upon its combustion (Saikia et al., 2015b) which is disadvantageous due to slagging, abrasion and fouling, leading to ash fusion inside the boiler. Moreover, leaching of potentially toxic trace elements from ash makes them bio-available, while the emission of micron- and nano-sized ash particles de- 
grade the quality of the environment and human health (Kumar et al., 2015). An Indian (Assam) coal chemistry group, led by Binoy K. Saikia, has been actively working on the production of advanced carbon materials from cheap bio-stock, such as low-grade coals and waste carbon materials, for advanced applications in society. Also, they are focused on energy and environment topics. Herewith, Saikia et al. (2014) demonstrate the application of ultrasonic energy $(20 \mathrm{kHz})$ to a few high-S Indian coals in aqueous and mixed alkali media (1:1 $\mathrm{KOH}$ and $\mathrm{NaOH}$ ) in order to remove $\mathrm{S}$ and ash for various industrial applications. The study showed maximum ash, pyritic $\mathrm{S}$, sulphate $\mathrm{S}$, and total $\mathrm{S}$ removal as follows: $87.52 \%, 83.92 \%, 12.50 \%$, and $18.80 \%$, respectively. The XRD and FTIR spectral analyses revealed a reduction in ash and different forms of $\mathrm{S}$ by use of ultrasonic energy. According to the ash fusion temperatures and the calorific values of the ultrasonicated coal samples, the quality of coal was greatly improved, while the coal leachates after ultrasonication were found to be predominant in non-hazardous $\mathrm{K}, \mathrm{Ca}$ and $\mathrm{Mg}$. Furthermore, Saikia et al. (2016) applied the ultrasonic energy in an aqueous $\mathrm{H}_{2} \mathrm{O}_{2}$ medium to remove $\mathrm{S}$ and ash from Brazilian coal. The study showed the maximum removal of $87.52 \%$ total S. The authors demonstrated how to replace other conventional clean-coal technologies in terms of less energy, less treatment time, less reagent volume, and low reagent concentrations. Noteworthy, they suggest that the method may be used in larger-scale trials with high-S and high-ash coals worldwide for a long time, due to the partially green nature of the procedure. In the study carried out by Saikia et al. (2014), ionic liquids were examined for the extractive desulphurisation and de-ashing of high-S sub-bituminous Indian coals. The ionic liquids, 1-n-butyl-3-methylimidazolium tetrafluoroborate and 1-n-butyl 3-methylimidazolium chloride, were employed in the presence of $\mathrm{HCOOH} / \mathrm{H}_{2} \mathrm{O}_{2}$ and $\mathrm{V}_{2} \mathrm{O}_{5}$. The maximum removal values were as follows: $50.2 \%$ total S, $48.0 \%$ organic S, and $70.3 \mathrm{wt} \%$ ash. Hereby, the study demonstrated high efficiency of removing significant amounts of inorganic as well as organic sulphur (aryls) components from the originally high-S coal. Apart from being a target for cleaning technology experiments and geochemical investigations, coal has been used for the production of advanced carbon materials. Das et al. (2017) report results of their study on supercapacitor electrode materials produced from low-grade coal by using wet-chemical methods. Namely, the authors note that there is a growing need to develop new types of clean and sustainable energy conversion and storage systems, such as batteries and supercapacitors for electric vehicles with low exhaust emissions. They also emphasize that supercapacitors are energy storage devices which have received tremendous attention due to their high power density, short charging time, and long cycling life, thus achieving better fuel economy, decreasing harmful emissions, and re- ducing the reliance on petroleum sources. Moreover, Das and Saikia (2017) fabricated carbon nanomaterials, i.e. nanodiamonds from low-grade coals during lowpower ultrasonic-assisted stimulation in hydrogen peroxide followed by dialysis in $1 \mathrm{kDa}$. These nanomaterials have promising applications in bioimaging engineering, photovoltaics, and optoelectronics.

The biological bioremediation approach, by using microorganisms to transform or degrade contaminants to make them environmentally non-hazardous, is regarded as a cost-effective remediation technology appropriate for large polluted soil and water areas. It has been successfully employed and developed by Indian scientists from Banaras Hindu University (BHU, Varanasi, Uttar Pradesh), Professors Prakash K. Singh and Asha Lata Singh. They have been using mixed bacterial consortium to explore the possibility of removal of potentially toxic trace elements from coal (Singh et al., 2012a, 2015b). They have found out that the removal efficiency was more than $80 \%$ for $\mathrm{Ni}, \mathrm{Zn}, \mathrm{Cd}, \mathrm{Cu}$, and $\mathrm{Cr}$, and $45 \%$ in the case of $\mathrm{Pb}$. The authors have also been working on the desulphurisation of coal by using microorganisms Ralstonia sp and Pseudoxanthomonas sp (Singh et al., 2012b). One of their latest papers (Singh et al., 2017a) presents the results of the petrological considerations in relation to the demineralization of Rajmahal Gondwana coals by means of Pseudomonas mendocina B6-1. Following the treatment, a significant reduction in the elemental content of oxygen, hydrogen and sulphur was observed. A gradual reduction of the pyrite phase due to bioleaching was identified and its signatures were reflected in XRD spectra and FTIR absorption bands. The authors also determined that some minerals occur intergrown with inertinites, thus causing the restricted bacterial action due to inadequate exposure of mineral particles and less surface area available for bioleaching. Also, their latest paper (Kumar et al., 2017b) reports the results of demineralization of the Karanpura Gondwana coals enriched in ash $(30.57 \%-21.80 \%)$ and low in sulphur $(0.29 \%-0.20 \%)$. They treated coal with Pseudomonas mendocina strain B6-1. The optimum conditions for effective demineralization were as follows: $\mathrm{pH}$ 6.0 , temperature $35^{\circ} \mathrm{C}, 6.0 \%$ (w/v) of pulp density, and incubation time of 7 days. Moreover, the treatment proved to increase the useful heat value, gross calorific value and net calorific value of coal. Hereby, the authors showed that their methodology was eco-friendly and useful in obtaining clean fuel.

In China, the coal consumption for power generation had increased from 196 Mtce in 1991 to 684 Mtce in 2005 , and the ratio of coal used for power generation relative to the total coal consumption increased from $26.0 \%$ to $44.6 \%$ in the same period (Chen and $\mathbf{X u}$, 2010). The authors outlined clean-coal technologies in China, presenting supercritical and ultra-supercritical boilers, circulating fluidized bed combustion, integrated gasification combined cycles, together with R\&D trends, 
and demonstration on carbon capture and storage technologies. The leading Chinese coal researcher Professor Shifeng Dai is actively investigating geochemical features of coal, specifically in the context of exploitation of economically important trace elements (Dai et al., 2016). Also, Dai and Finkelman (2017) elaborate the fact that coals are economic sources of strategically important elements, such as $\mathrm{Ge}, \mathrm{Ga}, \mathrm{U}, \mathrm{V}, \mathrm{Se}$, rare earth elements, Y, Sc, Nb, Au, Ag, and Re, as well as base metals $\mathrm{Al}$ and $\mathrm{Mg}$. Their extraction and utilisation from coal could result in a number of benefits, which will make this source an economically and environmentally attractive option, especially in China, USA, Russia, India, and other major coal user countries for the foreseeable future.

The leading US coal petrology and coal geochemistry researcher is James C. Hower (UKY, Lexington, Kentucky). He and his domestic as well as international coauthors are actively studying coal from all around the globe. To name a few papers, they investigated the distribution of REEs (Hower et al., 2016a, b), and $U$ and radionuclides (Hower et al. 2016c) in coal, and $\mathrm{Hg}$ content in fly ash (Hower et al., 2017). Also, he participated in a medical multidisciplinary study carried out by Wang et al. (2014). The authors carried out the isolation and structural elucidation of a new tetracyclic polyketide (ruthmycin) from Streptomyces sp. RM-4-15, a bacteria isolated near thermal vents from the Ruth Mullins underground coal mine fire in eastern Kentucky. Preliminary in vitro antibacterial, anticancer and antifungal assays revealed ruthmycin to display moderate antifungal activity. A multidisciplinary study, carried out by an international research group (Yang et al., 2017), reports that the coal combustion results in large quantities of otherwise rare Magnéli phases $\left(\mathrm{Ti}_{\mathrm{x}} \mathrm{O}_{2 \mathrm{x}-1}\right.$ with $4 \leq \mathrm{x} \leq 9$ ) from $\mathrm{TiO}_{2}$ minerals naturally present in coal. The authors note that this provides a new tracer for tracking solid-state emissions worldwide from industrial coalburning. In its first toxicity testing, they have shown that nanoscale Magnéli phases have potential toxicity pathways that are not photoactive like $\mathrm{TiO}_{2}$ phases, but instead seem to be biologically active without photostimulation. The authors suggest that these phases should be thoroughly tested for their toxicity in the human lung. Regarding clean-coal technologies in the USA, Ruth (2014) discusses them by presenting gasification, gas purification and separation, combustion turbines, fuel cells, and advanced steam cycles, that are likely to play key roles in the design of near-zero emission plants. The author elaborates critical materials, e.g. refractory linings for coal gasifiers, gas filters and sorbent systems to remove contaminants, ceramic membranes for separating oxygen from air and hydrogen from carbon dioxide, blading and other components for high-temperature combustion turbines, fuel cell electrodes and electrolytes, and boiler tubing and turbine components for advanced steam cycles.

\section{Indian research related to coal, environment, and technology}

Unlike Croatia, coal petrology and coal geochemistry research in India is a very active scientific discipline, and one of the leading experts is Professor Prakash K. Singh (BHU), whose few latest papers are briefly introduced here. Singh et al. (2017b) adopted an integrated approach to study the lignite deposits of Surkha mine associated with the Khadsaliya Clays Formation (Eocene) of the Saurashtra Basin, in Western India. Organic petrographic, palynofacies and geochemical data of the sampled succession have been acquired and discussed. Additionally, the authors used palynological and biomarker evidence to infer the organic composition, quality, thermal maturity, origin and depositional environment of the Surkha lignites, including the hydrocarbon source potential of the lignite-bearing sequence. Singh et al. (2017c) investigated the lignite deposits of the Cambay basin of Gujarat in order to understand their petrological and geochemical attributes, as petrological data about them are scarce compared to the wealth of literature available on Indian Gondwana coals. Singh et al. (2017d) carried out investigations on the lignite deposits of the Kachchh Basin. The petrographic analysis of the lignites indicates a dominance of the huminite group of macerals which is mainly contributed by ulminite-A, ulminite-B, attrinite, densinite, and phlobaphinite. Mineral matter is present in moderate concentrations, while $\mathrm{S}$ content is high. The study indicates on the conditions of flooded forest swamps with a few drier periods.

Environmental sustainability in India has been investigated by a BHU research group led by Professor Tirthankar Banerjee. They measure atmospheric trace gases and aerosols from various observational platforms, aiming to predict changes in atmospheric constituents and their repercussions on the climate. Herewith, their paper (Banerjee et al., 2016) explores the possibility of a policy revision regarding clean air quality in a recently launched nationwide campaign, Clean India Mission. According to them, India has reasonably progressed in developing sanitary facilities and disseminating clean fuel to its urban households, but the situation in rural areas is still miserable and needs to be reviewed. Also, several policy interventions and campaigns were made to improve the situation, but the outcomes have been remarkably poor. In conclusion, the authors recommend effective policy revision to disseminate clean energy, especially to rural people, and to assess human health impacts from air pollution.

Waste-water treatment technologies are being actively developed in India by numerous researchers. One Jaipur group is led by Professor Neha Sharma. Their paper (Sharma et al., 2013) presents the results of an investigation of textile wastewater in Rajasthan. By means of isolation and characterization of the indigenous bacte- 
rial strains which would decolourise textile diazo dye, the authors isolated 10 bacterial strains and screened them for their dye decolourising efficacy. The efficacies of bacterial strains were as follows: Staphylococcus sp. $82.5 \%$, Serratia sp. $84.0 \%$, and Micrococcus sp. $76.5 \%$. Sharma et al. (2017a) outline the potential of microorganisms to clean and modify the complex organic compounds, which are xenobiotic in nature, to simple water soluble products by a process of biomineralization. They elaborate how this capability largely depends upon the selective microbial community as well as on the structural and functional groups of toxic compounds. The microorganisms may be either indigenous to a contaminated area or isolated from elsewhere and brought to the contaminated site. The authors point out that different enzyme systems and genes are responsible for the degradative bioprocesses in waste water systems. Also, the diversity based studies should demonstrate a breakthrough in microbial ecology and environmental biotechnology domains. Furthermore, Sharma et al. (2017b) shows how bio-nanotechnological solutions can be of a paramount importance in circumventing the issues associated with wastewaters. The authors demonstrate a great potential of nanoparticles in wastewater treatment. Their unique characteristic of a high surface area can be used efficiently for removing toxic metal ions, disease causing microbes, organic and inorganic solutes from wastewater. Various classes of nanomaterials include metal-containing nanoparticles, carbonaceous nanomaterials, zeolites and dendrimers. This paper presents a comprehensive review of recent advances on different nanomaterial based mitigation strategies. A special emphasis was given to a green synthesis of nanoparticles aimed to address problems associated with waste-water effluents through the nano-bioremediation.

\section{Croatian research related to coal, environment, and technology}

Coal petrology research does not exist in Croatia at all as the coal mining (SHOS Raša) ceased altogether some 17-20 years ago. Coal studies have been mainly focused on detrimental consequences of SHOS Raša coal mining and combustion (Medunić et al., in press) on the environment of the PPP area (see Fig. 1 in Rađenović et al., 2016a). It has been a major source of the Croatian energy production since the early 20th century. Due to high values of $\mathrm{S}$, PAHs (polycyclic aromatic hydrocarbons), and radioactivity in coal, soil around the PPP was found to be severely polluted with S and PAHs (Medunić et al., 2016b) as well as with Ra-226 (Ernečić et al., 2014), while Fiket et al. (2016) determined peculiar REE patterns in studied soil samples. PAHs are typical products of anthropogenic processes (Naik, 2016). Their total concentrations in topsoil varied from $31 \mathrm{ng} / \mathrm{g}$ in control soil samples, to $13,535 \mathrm{ng} / \mathrm{g}$ at a distance of $100 \mathrm{~m}$ from the PPP (Medunić et al., 2016b). The authors ascribed
PAHs mainly to the coal-combustion processes, and to the additional contribution from a nearby unburnt coal pile subjected to casual very strong NE winds. Also, several conference abstracts have been published lately on various topics related to environmental pollution derived from SHOS Raša coal mining (Medunić et al., 2016c), distribution of sulphur isotopes in soil and coal (Malenšek et al., 2017), and human health risk assessment indices (Medunić et al., 2017a, b).

Frančišković-Bilinski et al. (2017) described magnetic and chemical properties of karstic river sediments contaminated by discharge of coal bottom ash and ash. They found very high magnetic susceptibility close to the pollution source, and strong correlations with $\mathrm{Co}, \mathrm{Fe}$, $\mathrm{Sr}, \mathrm{Al}, \mathrm{U}$ and B. Oreščanin et al. (2012) analysed fly and bottom ash in a former sulphate pulp factory. Compared to the world's average soil concentration, $U$ and Th values were increased 3.7 and 1.7 times, respectively. The mean value of the total effective dose rate measured in the air at the height of $1 \mathrm{~m}$ for all samples of ash and soil under the influence of the landfill was $1.60 \mathrm{mSv} / \mathrm{yr}$. Compared to the Croatian average $(0.7015 \mathrm{mSv} / \mathrm{yr})$, the determined mean value for the landfill was double. However, the mean value of the total effective dose rate measured above the landfill was 11.4 times the local background $(0.14 \mathrm{mSv} / \mathrm{yr})$. The authors suggested that the fly and bottom ash landfill should be sealed with a 10 $\mathrm{cm}$ thick layer of a material with low permeability to prevent redistribution of the radionuclides and heavy metals from the deposited material into the environment. Sofilić et al. (2013) investigated soil at an old metallurgical landfill site exposed to direct influence of metallurgical non-hazardous waste for many years. The obtained results point at contamination of soil with $\mathrm{Cu}$ according to the legislation of all observed EU countries, with Cd according to the legislation of Italy, Poland, and Belgium (Wallonia), and with $\mathrm{Cr}$ according to the legislation of Finland and Poland.

Regarding waste-water treatment technologies, Rađenović et al. (2013) analysed ladle furnace slag (LFS), which is a byproduct from further refining molten steel after coming out of a basic oxygen furnace or an electric arc furnace. The authors determined that the LFS proved to be an effective adsorbent for the removal of toxic metal ions from various industrial waste-waters. They also point out that the slag is a cheap and abundant, non-hazardous industrial waste as the ecotoxicity evaluation of its eluate showed that it did not contain constituents which might in any way adversely affect the environment. Furthermore, Rađenović and Medunić (2015) investigated removal of $\mathrm{Cr}(\mathrm{VI})$ from aqueous solution by a commercial carbon black. By testing the adsorbent dose, solution $\mathrm{pH}$, contact time, initial metal concentration, and temperature, the authors discovered that an initial solution of $\mathrm{pH} 2.4$ was the most favourable for $\mathrm{Cr}(\mathrm{VI})$ removal. The equilibrium data best fitted the Freundlich isotherm model, while the maximum adsorption 
capacity was found at $33.22 \mathrm{mg} / \mathrm{g}$. The thermodynamic parameters showed that $\mathrm{Cr}(\mathrm{VI})$ adsorption on the carbon black was a spontaneous exothermic process. Rađenović et al. (2016b) examined the adsorption potential of LFS for $\mathrm{Cr}(\mathrm{VI})$ ions from aqueous solutions. They found that the value of their maximum removal was $22.3 \mathrm{mg} / \mathrm{g}$ at $\mathrm{pH} 4.3$ and temperature of $293 \mathrm{~K}$. It was determined that the $\mathrm{Cr}(\mathrm{VI})$ adsorption mechanism was complex, while the film diffusion, and the intra-particle diffusion both contributed to the rate-determining step. Regarding the thermodynamic parameters, i.e. free energy change, enthalpy change, and entropy change, it was revealed that the $\mathrm{Cr}(\mathrm{VI})$ adsorption onto the LFS was endothermic and spontaneous.

\section{Conclusions}

This paper introduced several of the most intriguing and advanced topics in coal research, carried out by leading scientific authorities in India, China, and the USA. It showed versatility and importance of this material which is still vibrantly powering industries as well as scientific research. This paper also briefly summarised the latest Indian and Croatian research on coal, environment, and clean technologies from various aspects and domains. It is evident that Indian coal and technology research articles far exceed the Croatian ones, not only in terms of their total number, but also in relation to the strength and novelty of research topics. However, this paper, having resulted from an Indian-Croatian collaboration, exemplifies that future collaborations among environmental and chemical scientists as well as technologists from the two countries should be more intensive. Herewith, the Croatian environmental and clean technology science could advance towards a better perception by international scientists; also, some new collaborative initiatives should more closely connect Indian scientists with their peers in the EU.

\section{Acknowledgment}

The first author (G.M.) is especially indebted to Dr. Massimo Zacchini (Italian National Research Council, Institute of Agro-envinronmental and Forest Biology IBAF, Rome, Italy) and Dr. Paras Pujari (CSIR-NEERI, Water Technology and Management Division, Nagpur, India) for their efforts while managing the TECO project (the Indo-Italian research) which is funded by the European Union - Delegation of the European Union to India in collaboration with the EuropeAid Cooperation Office. Thanks to the TECO grant ("EU-India project TECO ICI+/2014/342-817-Technological eco-innovation for the quality control and the decontamination of polluted waters and soils"), the first author was able to spend the whole of November 2017 in India, having participated in a collaborative study entitled 'Decontamination of SHOS Raša coal and soil polluted by Raša coal using bacterial biomass: a case study of coal and soil from the Labin city area (North Adriatic, Croatia)', and discussed with colleagues (BHU, Dptm. of Geology, Varanasi, Uttar Pradesh) further steps towards a joint environmental scientific work on a Croatian locality polluted with SHOS Raša coal.

\section{References}

Banerjee, T., Kumar, M., Mall, R.K., Singh, R.S. (2016): Airing 'clean air' in Clean India Mission. Environmental Science and Pollution Research, 24(7), doi: 10.1007/s11356016-8264-y

Baruah, B.P., Saikia, B.K., Kotoky, P., Rao, P.G. (2006): Aqueous leaching on high sulfur sub-bituminous coals, in Assam, India. Energy \& Fuels, 20, 1550-1555.

Baruah, R., Kalita, D.J., Saikia, B.K., Gautam, A., Singh, A.K., Boruah, H.P.D. (2016): Native hydrocarbonoclastic bacteria and hydrocarbon mineralization processes. International Biodeterioration \& Biodegradation, 112, 18-30.

Burgos, W.D., Borch, T., Troyer, L.D., Luan, F., Larson, L.N., Brown, J.F., Lambson, J., Shimizu, M. (2012): Schwertmannite and Fe oxides formed by biological low-pH Fe(II) oxidation versus abiotic neutralization: impact on trace metal sequestration. Geochimica et Cosmochimica Acta, 76, 29-44.

Chen, W., Xu, R. (2010): Clean coal technology development in China. Energy Policy, 38, 2123-2130.

Chikkatur, A.P., Sagar, A.D., Sankar, T.L. (2009): Sustainable development of the Indian coal sector. Energy, 34, 942-953.

Dai, S., Yan, X., Ward, C.R., Hower, J.C., Zhao, L., Wang, X., Zhao, L., Ren, D., Finkelman, R.B. (2016): Valuable elements in Chinese coals: a review. International Geology Review, http://dx.doi.org/10.1080/00206814.2016.1197802.

Dai, S., Finkelman, R. (2017): Coal as a promising source of critical elements: Progress and future prospects. International Journal of Coal Geology, https://doi.org/10.1016/j. coal.2017.06.005.

Das, T., Chauhan, H., Deka, S., Chaudhary, S., Boruah, R., Saikia, B.K. (2017): Promising carbon nanosheet-based supercapacitor electrode materials from low-grade coals. Microporous and Mesoporous Materials, 253, 80-90.

Das, T., Saikia, B.K. (2017): Nanodiamonds produced from low-grade Indian coals. ACS Sustainable Chemistry and Engineering, 5, 9619-9624.

Dreher, G.B., Finkelman, R.B. (1992): Selenium mobilization in a surface coal mine, Powder River Basin, Wyoming, U.S.A. Environmental Geology and Water Science, 19, 155-167.

Ernečić, G., Lovrenčić Mikelić, I., Medunić, G. (2014): Distribution of 226Ra in the surface soil in the vicinity of the thermal power plant Plomin (Croatia). In: Pál-Molnár, E. (Ed.), Acta Mineralogica-Petrographica, Abstract Series, p. 28 (Szeged, Hungary).

Fiket, Ž., Medunić, G., Kniewald, G. (2016): Rare earth elements distribution in soil nearby thermal power plant. Environmental Earth Sciences, 75, 598. 
Finkelman, R.B. (1994): Modes of occurrence of potentially hazardous elements in coal: levels of confidence. Fuel Processing Technology, 39, 21-34.

Frančišković-Bilinski, S., Bilinski, H., Maldini, K., Milović, S., Zhang, Q., Appel, E. (2017): Chemical and magnetic tracing of coal slag pollutants in karstic river sediments. Environmental Earth Sciences, 76: 476.

Harkness, J.S., Sulkin, B., Vengosh, A. (2016): Evidence for coal ash ponds leaking in the Southeastern United States. Environmental Science and Technology, 50, 6583-6592.

Helios Rybicka, E. (1996): Impact of mining and metallurgical industries on the environment in Poland. Applied Geochemistry, 11, 3-9.

Höök, M., Zittel, W., Schindler, J., Aleklett, K. (2010): Global coal production outlooks based on a logistic model. Fuel, 89, 3546-3558.

Hower, J.C., Robl, T.L., Thomas, G.A. (1999): Changes in the quality of coal combustion by-products produced by Kentucky power plants, 1978 to 1997: consequences of Clean Air Act directives. Fuel, 78, 701-712.

Hower, J.C., Granite, E.J., Mayfield, D., Lewis, A., Finkelman, R.B. (2016a): Notes on Contributions to the Science of Rare Earth Element Enrichment: Minerals 6, doi: 10.3390/min6020032.

Hower, J.C., Eble, C.F., Dai, S., Belkin, H.E. (2016b): Distribution of rare earth elements in eastern Kentucky coals: Indicators of multiple modes of enrichment? International Journal of Coal Geology, 160-161, 73-81.

Hower, J.C., Dai, S., Eskenazy, G. (2016c): Distribution of uranium and other radionuclides in coal and coal-combustion products, with discussion of occurrences of CCPs in Kentucky power plants. Coal Combustion \& Gasification Products, 8, 44-53.

Hower, J.C., Clack, H.C., Hood, M.M., Hopps, S.G., Thomas, G.H. (2017): Impact of coal source changes on mercury content in fly ash: Examples from a Kentucky power plant. International Journal of Coal Geology, 170, 2-6.

Kumar, M., Singh, R.S., Banerjee, T. (2015): Associating airborne particulates and human health: Exploring possibilities. Environment International, 84, 201-202.

Kumar, M., Srivastava, R.K., Banerjee, T. (2017a): Climatic impacts of aerosols: a sustainability challenge. In: Environmental Science and Engineering, 1st ed., Chapter: Climate Change and Sustainable Technologies, Studium Press LLC, USA, Gurjar, B.R. (ed.), 11-27.

Kumar, A., Singh, A.K., Singh, P.K., Singh, A.L., Jha, M.K. (2017b): Demineralization study of high-ash Permian coal with Pseudomonas mendocina strain B6-1: a case study of the South Karanpura Coalfield, Jharkhand, India. Energy \& Fuels, DOI: 10.1021/acs.energyfuels.7b02562.

Medunić, G., Rađenović, A., Bajramović, M., Švec, M., Tomac, M. (2016a): Once grand, now forgotten: what do we know about the superhigh-organic-sulphur Raša coal?. Rudarsko-geološko-naftni zbornik, 34, 27-45.

Medunić, G., Ahel, M., Božičević Mihalić, I., Gaurina Srček, V., Kopjar, N., Fiket, Ž., Bituh, T., Mikac, I. (2016b): Toxic airborne S, PAH, and trace element legacy of the superhigh-organic-sulphur Raša coal combustion: Cytotoxicity and genotoxicity assessment of soil and ash. Science of The Total Environment, 566, 306-319.
Medunić, G., Šabarić, J., Krivohlavek, A., Divjak, D., Rađenović, A., Kampić, Š., Šeparović, A. (2016c): Sulphur and heavy metal pollution of the coal-based city soil (Labin, Croatia). Goldschmidt Abstracts, EAG, 2041-2041.

Medunić, G., Kljaković-Gašpić, Z., Fiket, Ž., Bituh, T., Kniewald, G. (2017a): Health risk assessment of potentially toxic trace elements in soil polluted by the Raša coal combustion in a Croatian coal-fired power plant. MedGeo'17, 7th International Conference on Medical Geology, Conference Materials, Moskva, 88-88.

Medunić, G., Kuharić, Ž., Krivohlavek, A., Fiket, Ž., Rađenović, A., Gödel, K., Bajramović, M. (2017b): Risk assessment of potentially toxic trace elements in soils and lettuce from the Raša coal mining and metal industry area (Labin city, Croatia). MedGeo'17, 7th International Conference on Medical Geology, Conference Materials, Moskva, 88-88.

Medunić, G., Kuharić, Ž., Krivohlavek, A., Fiket, Ž., Rađenović, A., Gödel, K., Kampić, Š., Kniewald, G. (in press): Geochemistry of Croatian superhigh-organic- sulphur Raša coal, imported low-S coal, and bottom ash: their Se and trace metal fingerprints in seawater, clover, foliage, and mushroom specimens. International Journal of Oil, Gas and Coal Technology, doi: 10.1504/IJOGCT.2018. 10006334

Malenšek, N., Medunić, G., Lojen, S., Zupančič, N. (2017): Sulphur isotopes in soil around the thermoelectric power plant Plomin (Croatia). Book of Abstract: ESIR Isotope Workshop XIV, Ionete, R. (ed.), Băile Govora, Vâlcea, 133-134.

Mishra, T., Hait, J., Aman, N., Jana, R.K., Chakravarty, S. (2007): Effect of UV and visible light on photocatalytic reduction of lead and cadmium over titania based binary oxide materials. Journal of Colloid and Interface Science, 316, 80-84.

Mishra, V., Bhowmick, T., Chakravarty, S., Varma, A.K., Sharma, M. (2016): Influence of coal quality on combustion behaviour and mineral phases transformations. Fuel, 186, 443-455.

Naik, A.S. (2016): Coal mining and organic pollutants: a case of Mahanadi basin coalfields, India. In book: Geostatistical and Geospatial Approaches for the Characterization of Natural Resources in the Environment, 373-379.

Nišić, D., Knežević, D., Sijerković, N., Pantelić, U., Banković, M. (2016): Comparative risk assessment of CCW disposal in the old and new landfill of the coal-fired power plant Kostolac based on the hydrological scenario. Technics, Special edition, Mining, Geology and Metallurgy, Union of engineers and technicians of Serbia, 25-32. doi: 10.5937/ tehnika1605677N

Oliveira, M.L., Marostega, F., Taffarel, S.R., Saikia, B.K., Waanders, F.B., DaBoit K., Baruah, B.P., Silva, L.F. (2014): Nano-mineralogical investigation of coal and fly ashes from coal-based captive power plant (India): an introduction of occupational health hazards. Science of the Total Environment, 468-469, 1128-636.

Oreščanin, V., Kollar, R., Buben, K., Mikelić, I.L., Kollar, K., Kollar, M., Medunić, G. (2012): Chemical and radiologi-

The Mining-Geology-Petroleum Engineering Bulletin and the authors $\odot$, 2018, pp. 13-21, DOI: 10.17794/rgn.2018.3.2 
cal characterization of fly and bottom ash landfill of the former sulfate pulp factory Plaški and its surroundings. Journal of Environmental Science and Health, part A: Toxic/Hazardous Substances and Environmental Engineering, 47, 1592-606.

Rađenović, A. (2004): Sumpor u ugljenu (Sulphur in coal, in Croatian).Kemija u Industriji, 53, 557-565.

Rađenović, A. (2006): Inorganic constituents in coal. Kemija u industriji, 55, 65-71.

Rađenović, A., Malina, J., Sofilić, T. (2013): Characterization of ladle furnace slag from carbon steel production as a potential adsorbent. Advances in Materials Science and Engineering, 2013, http://dx.doi.org/10.1155/2013/198240

Rađenović, A., Medunić, G. (2015): Removal of Cr(VI) from aqueous solution by a commercial carbon black. Desalination and Water Treatment, 55, 183-192.

Rađenović, A., Medunić, G., Saikia, B.K. (2016a): Comparative review of Croatian and Indian air pollution studies with emphasis on pollutants derived by coal combustion. Rudarsko-Geološko-Naftni Zbornik, 32, 1, 33-44.

Rađenović, A., Medunić, G., Sofilić, T. (2016b): The use of ladle furnace slag for the removal of hexavalent chromium from an aqueous solution. Metallurgical Research \& Technology, 113, 606-1-606-12.

Ruth, L.A. (2014): Advanced clean coal technology in the USA. Materials at High Temperatures, 20, 7-14.

Saikia, B.K., Boruah, R.K., Gogoi, P.K. (2007): FT-IR and XRD analysis of coal from Makum coalfield of Assam. Journal of Earth System Science, 116, 575-579.

Saikia, B.K., Goswamee, R.L., Baruah, B.P., Baruah, R.K. (2009): Occurrence of some hazardous metals in Indian coals. Coke and Chemistry, 52, 54-59.

Saikia, B.K., Dutta, A.M., Saikia, L., Ahmed, S., Baruah, B.P. (2014a): Ultrasonic assisted cleaning of high sulphur Indian coals in water and mixed alkali. Fuel Processing Technology, 123, 107-113.

Saikia, B.K., Khound, K., Baruah, B.P. (2014b): Extractive desulfurization and de-ashing of high sulfur coals by oxidation with ionic liquids. Energy Conversion and Management, 81, 298-305.

Saikia, J., Saikia, P., Boruah, R., Saikia, B.K. (2015a): Ambient air quality and emission characteristics in and around a non-recovery type coke oven using high sulphur coal. Science of the Total Environment, 530-531, 304-313.

Saikia, B.K., Hower, J.C., Hood, M.M., Baruah, R., Dekaboruah, H.P., Boruah, R., Sharma, A. and Baruah, B.P. (2015b): Petrological and biological studies on some fly and bottom ashes collected at different times from an Indian coal-based captive power plant. Fuel, 158, 572-581.

Saikia, B.K., Dalmora, A.C., Choudhury, R., Das, T., Taffarel, S.R., Silva, L.F.O. (2016): Effective removal of sulfur components from Brazilian power-coals by ultrasonication $(40 \mathrm{kHz})$ in presence of $\mathrm{H} 2 \mathrm{O} 2$. Ultrasonics Sonochemistry, 32, 147-157.

Sharma, N., Chatterjee, S., Bhatnagar, P. (2013): Assessment of physicochemical properties of textile wastewaters and screening of bacterial strains for dye decolourisation. Universal Journal of Environmental Research and Technology, 3, 345-355.
Sharma, N., Bhatnagar, P., Chatterjee, S., Goswami, P. (2017a): Waste water microbes and environmental "clean up": roadmap to environmental sustainability. International Journal of Advanced Research in Science, Engineering and Technology, 4, 3341-3350.

Sharma, N., Bhatnagar, P., Chatterjee, S., John, P.J., Soni, I.P. (2017b): Bio nanotechnological intervention: a sustainable alternative to treat dye bearing waste waters. Indian Journal of Pharmaceutical and Biological Research, 5, 17-24.

Singh, P.K., Singh, A.L., Kumar, A., Singh, M.P. (2012a): Mixed bacterial consortium as an emerging tool to remove hazardous tracemetals from coal. Fuel, 102, 227-230.

Singh, A.L., Singh, P.K., Kumar, A., Singh, M.P. (2012b): Desulfurization of selected hard and brown coal samplesfrom India and Indonesia with Ralstonia sp and Pseudoxanthomonas sp. Energy Exploration \& Exploitation, 30, 985-998.

Singh, P.K., Singh, A.L., Kumar, A., Singh, M.P. (2013): Control of different pyrite forms on desulfurization of coal with bacteria. Fuel, 106, 876-879.

Singh, A.L., Singh, P.K., Kumar, A., Yadav, A., Singh, M.P. (2014): Experimental study on demineralization of coal with Pseudomonas mendocina strain B6-1 bacteria to obtain clean fuel. Energy Exploration \& Exploitation, 32, 831-846.

Singh, A.L., Singh, P.K., Singh, M.P., Kumar, A. (2015a): Environmentally sensitive major and trace elements in indonesian coal and their geochemical significance. Energy Sources, Part A: Recovery, Utilization, and Environmental Effects, 37, 1836-1845.

Singh, A.L., Singh, P.K., Kumar, A., Singh, M.P. (2015b): Sequestration of metals from coal using bacteria: environmental implications on clean coal energy. Energy Sources, Part A: Recovery, Utilization, and Environmental Effects, 37, 1432-1439.

Singh, P.K., Singh, A.L., Kumar, A., Singh, M.P. (2017a): Petrological considerations for the demineralization of Rajmahal coals with Pseudomonas mendocina B6-1. Journal of the Geological Society of India, 89, 643-652.

Singh, V.P., Singh, B.D., Mathews, R.P., Singh, A., Mendhe, V.A., Singh, P.K., Mishra, S., Dutta, S., Shivanna, M., Singh, M.P. (2017b): Investigation on the lignite deposits of Surkha mine (Saurashtra Basin, Gujarat), western India: Their depositional history and hydrocarbon generation potential. International Journal of Coal Geology, 183, 78-99.

Singh, P.K., Singh, V.K., Singh, M.P., Rajak, P.K. (2017c): Petrographic characteristics and paleoenvironmental history of Eocene lignites of Cambay basin, Western India. International Journal of Coal Science and Technology, 4, 214-233.

Singh, P.K., Singh, V.K., Singh, M.P., Rajak, P.K. (2017d): Understanding the paleomires of Eocene lignites of Kachchh Basin, Gujarat (Western India): petrological implications. International Journal of Coal Science and Technology, 4, 80-101.

Sofilić, T., Brnardić, I., Šimunić-Mežnarić, V., Šorša, A. (2013): Soil pollution caused by landfilling of nonhazard- 
ous waste from steel production processes. Kemija u Industriji, 62, 381-388.

Wang, X., Elshahawi, S., Shaaban, K., Fang, L., Ponomareva, L., Zhang, Y., Copley, G., Hower, J., Zhan, C, Kharel, M., Thorson, J. (2014): Ruthmycin, a novel tetracyclic polyketide from Streptomyces sp. RM-4-15. Organic Letters, 16, 456-459.
Yang, Y., Chen, B., Hower, J.C., Schindler, M., Winkler, C., Brandt, J., Di Giulio, R., Ge, J., Liu, M., Fu, Y., Zhang, L., Chen, Y., Priya, S., Hochella Jr., M.F. (2017): Discovery and ramifications of incidental Magnéli phase generation and release from industrial coal-burning. Nature Communications, 8, 194, doi:10.1038/s41467-01700276-2.

\section{SAŽETAK}

\section{Pregled najnovijih istraživanja ugljena, okoliša i čistih tehnologija}

Fosilna goriva, posebno ugljen, nužni su izvori energije potrebni za današnji tehnološki i ekonomski napredak diljem svijeta. Njihovim spaljivanjem oslobađaju se brojni onečišćivači okoliša, poput $\mathrm{CO}_{2}, \mathrm{SO}_{2}$, te niz organskih i anorganskih spojeva. Međutim, iako su te emisije rezultirale zagađenjem zraka i problemima regionalnih zakiseljavanja oborina, ipak se ne može dokazati da je njihova uporaba u potpunosti zamijenjena izvorom energije koji bi ispuštao niske razine $\mathrm{CO}_{2}$. Ugljen, zbog jedinstvenoga sastava i obilježja, aktivno istražuju znanstvenici i tehnolozi iz različitih disciplina u potrazi za ekonomski vrijednim metalima i medicinski aktivnim tvarima. Isto tako, ugljen se rabi u izradi novih nanomaterijala u laboratorijima te za potrebe tehnologija obrade otpadnih voda i proizvodnje čistoga ugljena. Cilj rada bio je usredotočiti se na najnovija dostignuća istraživanja ugljena vodećih međunarodnih znanstvenika iz Indije, Kine i SAD-a. Također, u radu su ukratko predstavljeni odabrani radovi nekoliko indijskih i hrvatskih istraživačkih skupina koje se bave pitanjima zaštite okoliša i novih tehnologija za obradu otpada. Iako se dvije zemlje razlikuju u zemljopisnome, povijesnome, ekonomskome i industrijskome smislu, obje su pridobivale ugljen i primjenjivale ga u proizvodnji električne energije te pripadajućim teškim industrijama..

Ključne riječi:

ugljen, otpad, onečišćenje okoliša, tehnologija čistoga ugljena, bioremedijacija

\section{Authors contribution}

Gordana Medunić (Associate Professor) initialised an idea on the topic of the paper, and together with Ankica Rađenović (Full Professor) summarised papers on Croatian and world research. Deepti Mondol (Assistant Professor) and Sadhana Nazir (MSc.) compiled papers on Indian research. All the authors equally participated in typing and editing the manuscript. 